
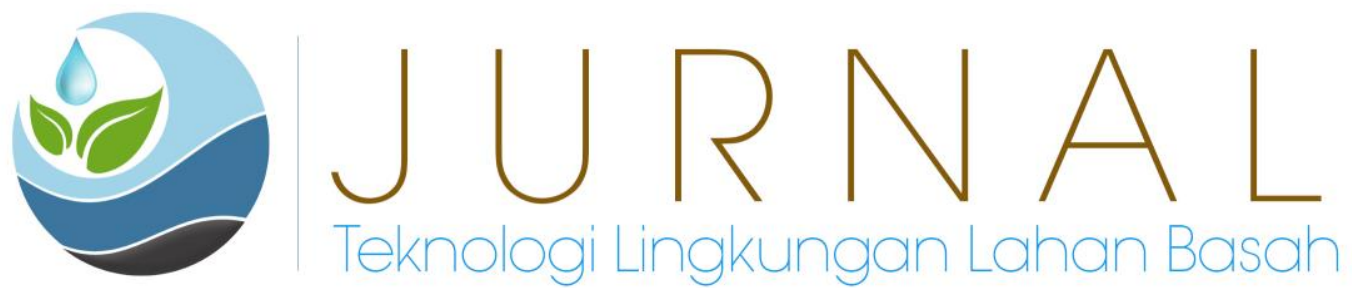

\title{
PENGARUH PASANG SURUT TERHADAP SEBARAN SALINITAS DI SUNGAI KAPUAS KECIL
}

\author{
Rizki Purnaini ${ }^{1}$, Sudarmadji $^{2}$, Suryo Purwono $^{3}$ \\ ${ }^{1}$ Program Doktor Ilmu Lingkungan Fakultas Pasca Sarjana UGM \\ ${ }^{2}$ Departemen Geografi Lingkungan, Fakultas Geografi UGM \\ ${ }^{3}$ Departemen Teknik Kimia, Fakultas Teknik, UGM \\ E-mail : rizkipurnaini@enviro.untan.ac.id
}

\begin{abstract}
Abstrak
Pada musim kemarau terjadi intrusi di Sungai Kapuas Kecil sehingga menyebabkan berubahnya kualitas air baku yang akan diolah oleh PDAM. Tujuan penelitian ini mengkaji pengaruh pasang surut terhadap sebaran salinitas di sungai Kapuas Kecil pada musim kemarau. Penelitian dilakukan di Sungai Kapuas Kecil bagian hilir sepanjang $\pm 30 \mathrm{~km}$. Metode penelitian yakni survey lapangan; pengambilan sampel air dan analisisnya; membuat grafik sebaran salinitas dan menentukan tipe estuari; serta metode statistik regresi-korelasi. Hasil penelitian sebaran salinitas secara horizontal di Sungai Kapuas Kecil dari hulu ke hilir cenderung terus meningkat pada saat pasang dengan jarak jangkauan air laut mencapai $\pm 20 \mathrm{~km}$ ke arah hulu sungai dengan nilai salinitas berkisar 1,5 ppt. Sebaran salinitas secara vertikal pada 3 lapisan kedalaman menunjukkan peningkatan salinitas dari lapisan permukaan menuju dasar perairan. Berdasarkan struktur salinitasnya tipe estuari Sungai Kapuas Kecil adalah "tercampur sebagian". Hasil analisis regresi linier berganda didapatkan nilai koefisien determinasi (adjusted R square) $=0,760$, menunjukkan bahwa pasang surut dan jarak berpengaruh terhadap kualitas air (nilai TDS) sebesar $76 \%$.
\end{abstract}

Kata kunci: Intrusi air permukaan; Musim Kemarau;Salinitas; Sungai Kapuas Kecil

\begin{abstract}
In dry season there is intrusion in Kapuas Kecil River is often a problem because it causes the change of raw water quality to be processed in Water Treatment Plant (WTP). The purpose of this study was to examine the effect of tides on the distribution of salinity in the Kapuas Kecil river during the dry season. The study was conducted in Kapuas River downstream along 30 $\mathrm{km}$. The research method used is a field survey; water sampling and analysis; graph of salinity distribution and determine the type of estuary; and statistical methods of regression. The results study of horizontal salinity distribution in the Kapuas Kecil River from upstream to downstream tend to continue to increase at high tide with a distance of sea water reach up to $20 \mathrm{~km}$ upstream with salinity values ranging from $1.5 \mathrm{ppt}$. Vertical salinity distribution at 3 layers of depth shows an increase in salinity from the surface layer to the bottom of the water. Based on the salinity structure, the estuary type of the Kapuas Kecil River is "partially mixed". The result of multiple linear regression analysis got the value of coefficient of determination (adjusted $R$ square) $=0,760$, that independent variable (tidal and distance) influence to dependent variable (value of TDS) equal to $76 \%$.
\end{abstract}

Keywords: Dry Seasons; Kapuas Kecil River; Salinity; Water Surface intrusion 

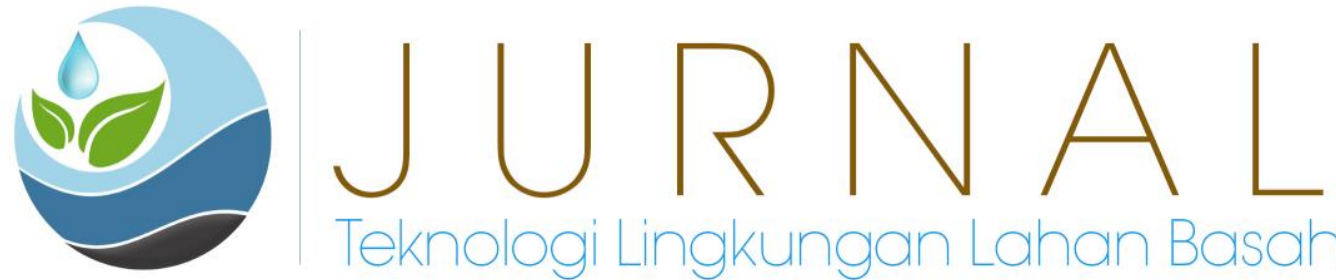

\section{PENDAHULUAN}

Sungai Kapuas Kecil merupakan anak sungai dari Sungai Kapuas di bagian hilir. Sungai Kapuas Kecil membelah dan melewati Kota Pontianak sebelum menuju muara ke Selat Karimata. Aliran sungai ini melewati kota dengan pemukiman padat penduduk beserta berbagai aktivitas masyarakatnya. Kota Pontianak banyak memiliki sungai kecil/parit yang berfungsi sebagai drainase dan sekaligus sebagai penampungan limbah domestik dimana semua sungai kecil/parit ini akhirnya bermuara ke sungai Kapuas Kecil.

Menurut BMKG berdasarkan distribusi data rata-rata curah hujan bulanan Kota Pontianak mempunyai Pola hujan equatorial, yang wilayahnya memiliki distribusi hujan bulanan bimodial dengan dua puncak musim hujan maksimum dan hampir sepanjang tahun masuk dalam kriteria musim hujan. Pola ekuatorial dicirikan oleh tipe curah hujan dengan bentuk bimodial (dua puncak hujan) yang biasanya terjadi sekitar bulan Maret dan Oktober atau pada saat terjadi ekinoks (kadarsah, 2007).

Sungai Kapuas Kecil sangat dipengaruhi oleh pasang surut air laut, Pada saat curah hujan rendah, intrusi air permukaan sering menjadi masalah bagi PDAM karena menjadi penyebab berubahnya kualitas air baku yang akan diolah. Intrusi air permukaan terjadi pada saat arus pasang tinggi tetapi debit aliran dari hulu sungai kecil pada saat curah hujan rendah.

Debit sungai dan perubahan musimannya adalah salah satu parameter penting dalam sirkulasi di estuari. Debit sungai tergantung pada karakteristik hidrologi dan daerah aliran sungai. Pada musim hujan debit aliran besar, sementara pada musim kemarau kecil. Pada umumnya debit sungai jauh lebih kecil daripada debit yang ditimbukan oleh pengaruh pasang surut. Pengaruh debit aliran lebih dominan di bagian hulu estuari dibanding dengan di sebelah hilir. Pada waktu banjir, debit sungai mendorong polutan ke laut, sedang pada debit kecil polutan bergerak lebih ke hulu. Arus pasang surut mempengaruhi pergeseran polutan di sepanjang estuari, yang bergerak ke hulu pada waktu air pasang dan ke hilir pada waktu air surut (Triatmodjo, 1999).

Sirkulasi aliran di estuari dipengaruhi oleh sifat-sifat morfologi estuari, pasang surut dan debit aliran dari hulu (debit sungai). Sirkulasi aliran tersebut meliputi penjalaran gelombang pasang surut, pencampuran antara air tawar dan air asin, gerak sedimen, polutan (biologis, kimiawi dan fisis), dan sebagainya (Triatmodjo, 1999).

Penjalaran gelombang pasang surut dari laut menuju estuari berlawanan arah dengan debit sungai yang mengalir menuju laut. Adanya perbedaan rapat massa antara air asin dan air tawar, maka akan terjadi pencampuran diantara keduanya. Tingkat pencampuran tergantung pada geometri estuari, pasang surut, debit sungai, perbedaan rapat massa antara air tawar dan air asin, angin, dan efek coriolis. Efek coriolis terjadi karena adanya pengaruh perputaran bumi (Triatmodjo, 1999).

Perbedaan salinitas di wilayah estuaria mengakibatkan terjadinya proses pergerakan masa air. Air asin yang memiliki masa jenis lebih besar dari pada air tawar, menyebabkan air asin di muara yang berada di lapisan dasar dan mendorong air tawar menuju laut. Proses pergerakan antara masa air laut dan air tawar ini menyebabkan terjadinya 

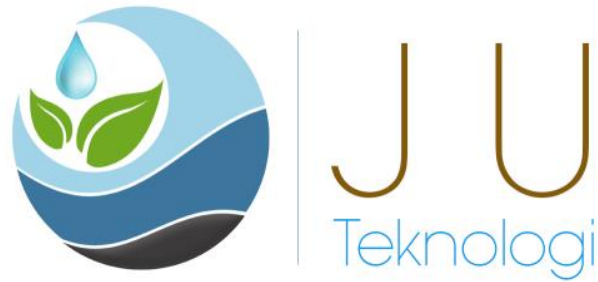

stratifikasi yang kemudian mendasari tipetipe estuari.

Pasang menghasilkan pencampuran dalam dua cara, yaitu: gesekan arus pasang surut di bagian bawah saluran menghasilkan turbulen dan mengarah ke pencampuran turbulen, dan interaksi dari gelombang pasang dengan batimetri menghasilkan arus skala besar (Fischer, et al., 1979).

Penelitian ini dilakukan dengan tujuan untuk mengkaji pengaruh pasang surut terhadap sebaran salinitas di sungai Kapuas Kecil bagian hilir pada musim kemarau.

\section{METODE PENELITIAN}

Penelitian dilaksanakan pada bulan Agustus 2016 di sungai Kapuas Kecil bagian hilir. Analisis curah hujan bulan Agustus 2016, sebagian besar wilayah Kalimantan Barat curah hujan berkisar antara 21-50 $\mathrm{mm}$, curah hujan terendah sebesar $7 \mathrm{~mm}$ terjadi di Kota Pontianak (BMKG, 2016). Lokasi penelitian adalah aliran sungai sepanjang $\pm 30 \mathrm{~km}$ dari batas hulu lokasi penelitian sampai ke muara. Batas hulu lokasi penelitian adalah letak lokasi intake PDAM Kubu Raya, sedangkan batas hilirnya adalah mulut sungai (muara). Data yang digunakan untuk penelitian ini adalah data primer berupa data salinitas ,TDS dan hidrometri sungai; dan data sekunder berupa data ramalan pasang surut dan debit sungai.

Metode yang digunakan adalah survey lapangan; pengambilan sampel air dan analisis insitu dan eksitu; membuat grafik
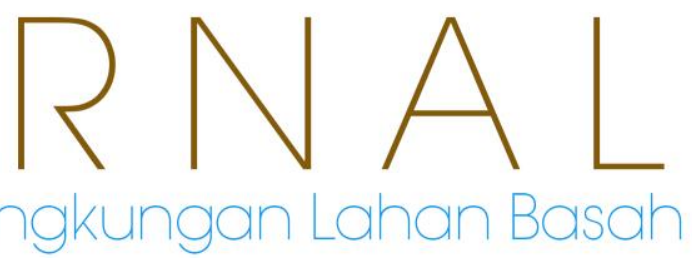

sebaran salinitas; dan menentukan tipe estuari. Metode penentuan jumlah dan lokasi stasiun pengambilan sampel menggunakan purposive sampling method. Pengambilan sampel air dilakukan di 7 (tujuh) lokasi stasiun pemantauan pada saat pasang dan surut (Gambar 2.1).Pengambilan sampel air sungai dilakukan sesuai SNI 6989.57:2008 dengan menggunakan perahu dan alat water sampler. Sampel air diambil di setiap stasiun pemantauan yang dibagi menjadi 3 titik melintang penampang sungai dan masing-masing pada tiga lapisan kedalaman yaitu lapisan permukaan $(0,2 d)$, tengah $(0,6 \mathrm{~d})$, dan dasar sungai $(0,8 \mathrm{~d})$ untuk kemudian dianalisis secara insitu menggunakan alat Extech instruments, ExStick EC 400 dan analisis di laboratorium.

Pengukuran penampang melintang sungai dan kedalaman sungai pada masing-masing stasiun pemantauan dilakukan menggunakan perahu, GPS dan echosounder. Pengamatan pasang surut dilakukan selama satu siklus pasang surut (15 hari) dengan menggunakan alat HOBO onset water level logger S/N: 10949770 yang dipasang di intake Imam Bonjol PDAM Kota Pontianak. Data hasil survey dan analisis sampel air selanjutnya dibuat grafik sebaran salinitas secara horizontal dan vertikal untuk menentukan tipe estuari dan analisis statistic dengan metode regresikorelasi untuk mengetahui pengaruh pasang surut terhadap kualitas air di Sungai Kapuas Kecil. 

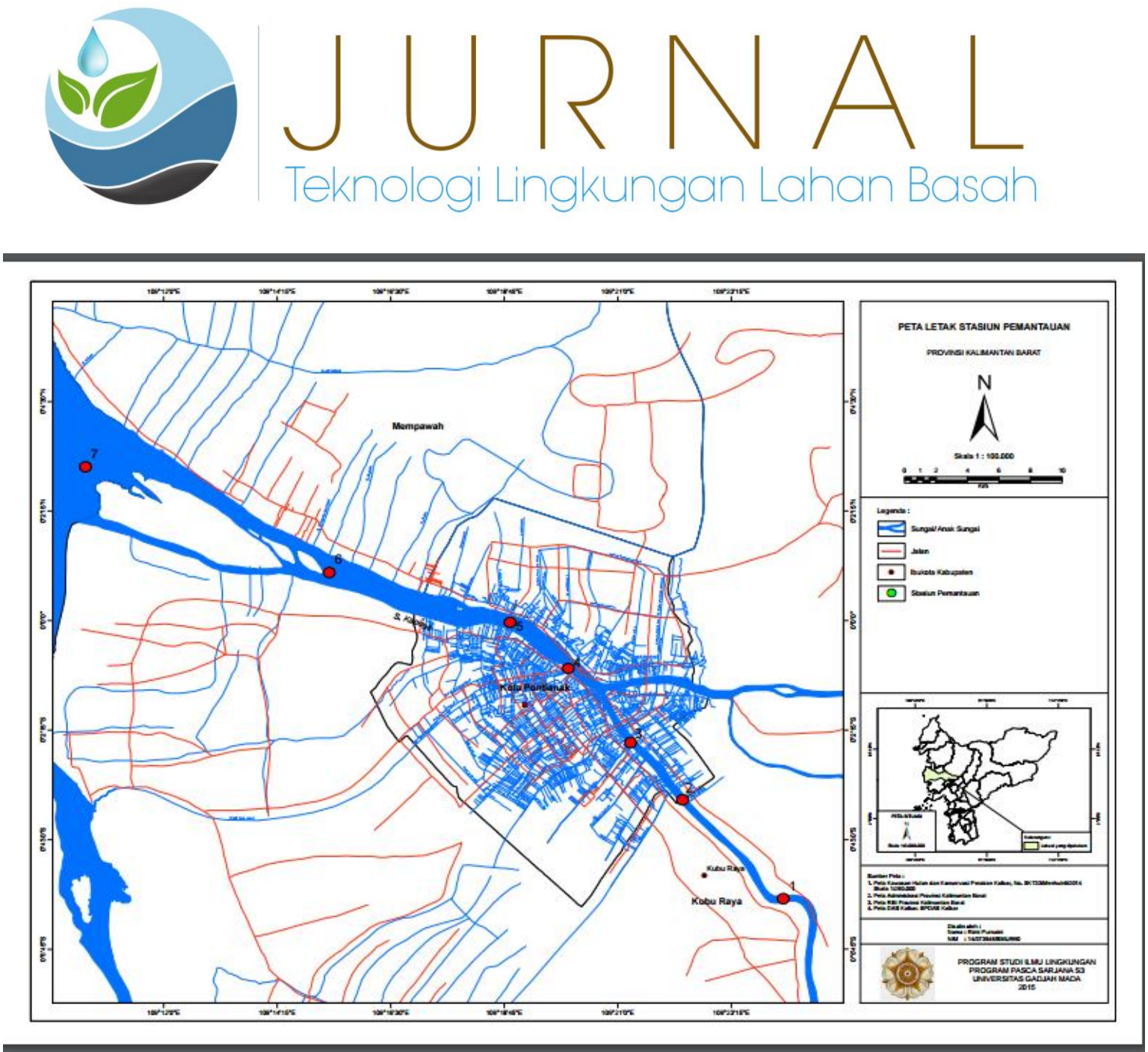

Gambar 1. Peta Lokasi Pengambilan Sampel Air di Sungai Kapuas Kecil

\section{HASIL DAN PEMBAHASAN}

Sungai Kapuas Kecil sangat dipengaruhi oleh pasang surut air laut, berdasarkan pengamatan yang telah dilakukan tipe pasang surut di Sungai Kapuas Kecil adalah tipe campuran dominan tunggal (mixed tide prevailing diurnal), dalam satu hari terjadi satu kali air pasang dan satu kali air surut tetapi kadang-kadang untuk sementara waktu terjadi dua kali pasang dan dua kali surut dengan tinggi dan periode yang sangat berbeda (Gambar 2). Elevasi muka air maksimum Sungai Kapuas Kecil bulan Agustus 2016: 1,6 m saat pasang dan 0,5 m saat surut, (DISHIDROS, 2016). Debit Sungai Kapuas Kecil pada saat pasang 1200 $\mathrm{m}^{3} /$ det dan pada saat surut $1234 \mathrm{~m}^{3} /$ det, Data ini didapat dari hasil pengukuran yang dilakukan untuk pekerjaan Rencana Jalan Outer Ringroad Kota Pontianak 26 november 2014. 

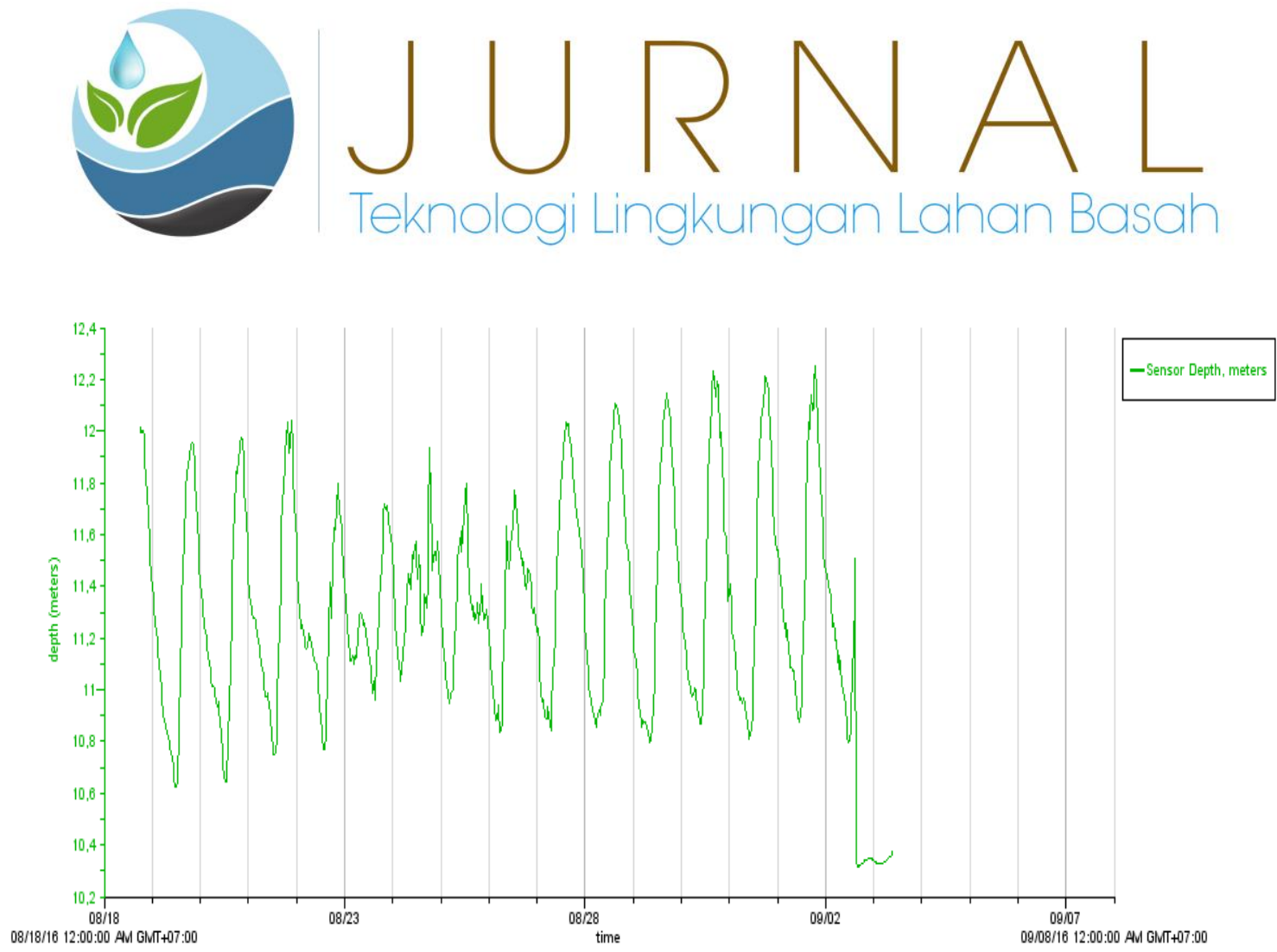

Gambar 2. Elevasi Pasang Surut di Sungai Kapuas Kecil Bulan Agustus 2016 Sumber: Purnaini, et al.,(2017)

Sebaran salinitas secara horizontal di estuari Sungai Kapuas Kecil dari hulu ke hilir pada musim kemarau cenderung terus meningkat pada saat pasang, salinitas di stasiun 1, 2, dan 3 berkisar 11,9 - 21,4 ppm, sedangkan pada stasiun 4, 5, 6, dan 7 yang letaknya semakin ke hilir salinitas berkisar 1,55 - 15 ppt. Perairan payau seperti muara biasanya salinitas berkisar 5 - 30 ppt. Tingginya kadar salinitas di lokasi stasiun pemantauan yang letaknya semakin ke hilir ini pada semua lapisan kedalaman terjadi karena adanya massa air laut yang masuk ke sungai pada saat pasang. Sebaran salinitas secara horizontal di lokasi penelitian dari hulu ke hilir cenderung meningkat pada saat pasang (Gambar 3).

Pengaruh pasang surut terhadap kenaikan nilai salinitas signifikan dengan bertambahnya jarak stasiun pengamatan yang semakin menuju kearah hilir/muara sungai. Jarak jangkauan air laut relatif jauh, $\pm 20 \mathrm{~km}$ ke arah hulu sungai dimana nilai salinitas pada lokasi ini berkisar 1,5 ppt.
Dalam arah memanjang, salinitas akan semakin bertambah atau naik seiring dengan bertambahnya jarak dari hulu sungai ke arah hilir/muara ataupun sebaliknya akibat adanya pengaruh pasang surut,karakteristik estuari, dan debit sungai Triatmodjo (1999). Penelitian Sedyoko, et al., (2013) juga menunjukkan jarak jangkauan salinitas berpengaruh nyata terhadap perubahan nilai salinitasnya. Meskipun jarak jangkauan air laut relatif jauh, pengaruh kenaikan nilai salinitas signifikan dengan bertambahnya jarak stasiun pengamatan yang semakin menuju kearah hilir/muara sungai. Bertambahnya jarak menuju hulu sungai, nilai salinitas semakin berkurang (Dewi, et al.,2016).

Sebaran salinitas secara vertikal pada tiga lapisan kedalaman masing-masing stasiun pemantauan di lokasi penelitian ditunjukkan pada Gambar 4 dan Gambar 5. Peningkatan salinitas dari lapisan permukaan menuju dasar perairan disebabkan air laut masuk ke estuaria 

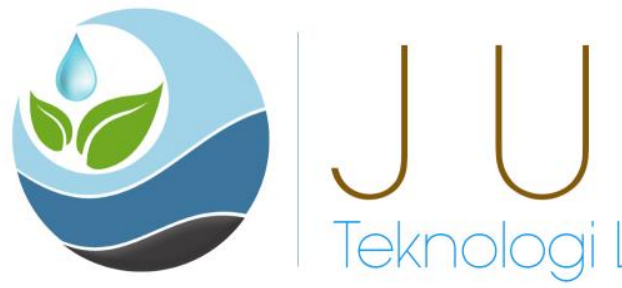

melalui lapisan bawah sedangkan air tawar di lapisan permukaan. Sebaran salinitas yang paling rapat terjadi di dasar sungai karena konsentrasi air laut lebih besar dibandingkan dengan konsentrasi air tawar, maka setiap penambahan kedalaman sungai akan menambah nilai salinitas di stasiun tersebut dengan nilai yang bervariasi antar stasiunnya (Sedyoko, et al., 2013). Lapisan kedalaman sungai berpengaruh terhadap distribusi salinitas secara vertikal. Salinitas akan semakin besar nilainya dengan bertambahnya kedalaman, hal ini disebabkan karena massa jenis air laut yang lebih besar daripada air tawar, yang mengakibatkan air asin berada dilapisan bawah sehingga nilai salinitas akan
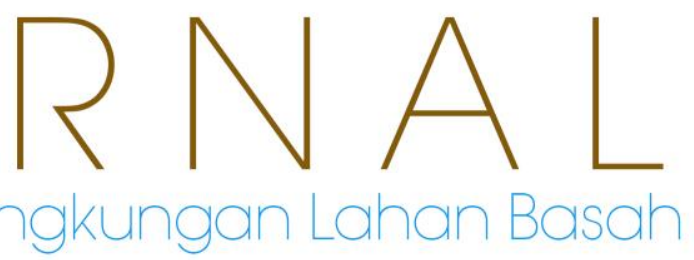

meningkat pada dasar sungai (Hutabarat dan Evan 2006). Hasil penelitian Dewi, et al., 2016 juga mendapatkan bahwa pada distribusi salinitas secara vertikal, nilai salinitas akan bertambah dengan bertambahnya kedalaman.

Berdasarkan struktur salinitasnya estuari Sungai Kapuas Kecil memiliki tipe estuari tercampur sebagian. Hal ini berdasarkan ciri-ciri tipe estuari ini yang dijelaskan dalam Triatmodjo (1999), salinitas bervariasi dalam arah memanjang dan vertikal. Dalam arah memanjang, salinitas berkurang dari mulut sungai ke arah hulu, sedangkan dalam arah vertikal berkurang dari dasar ke permukaan.

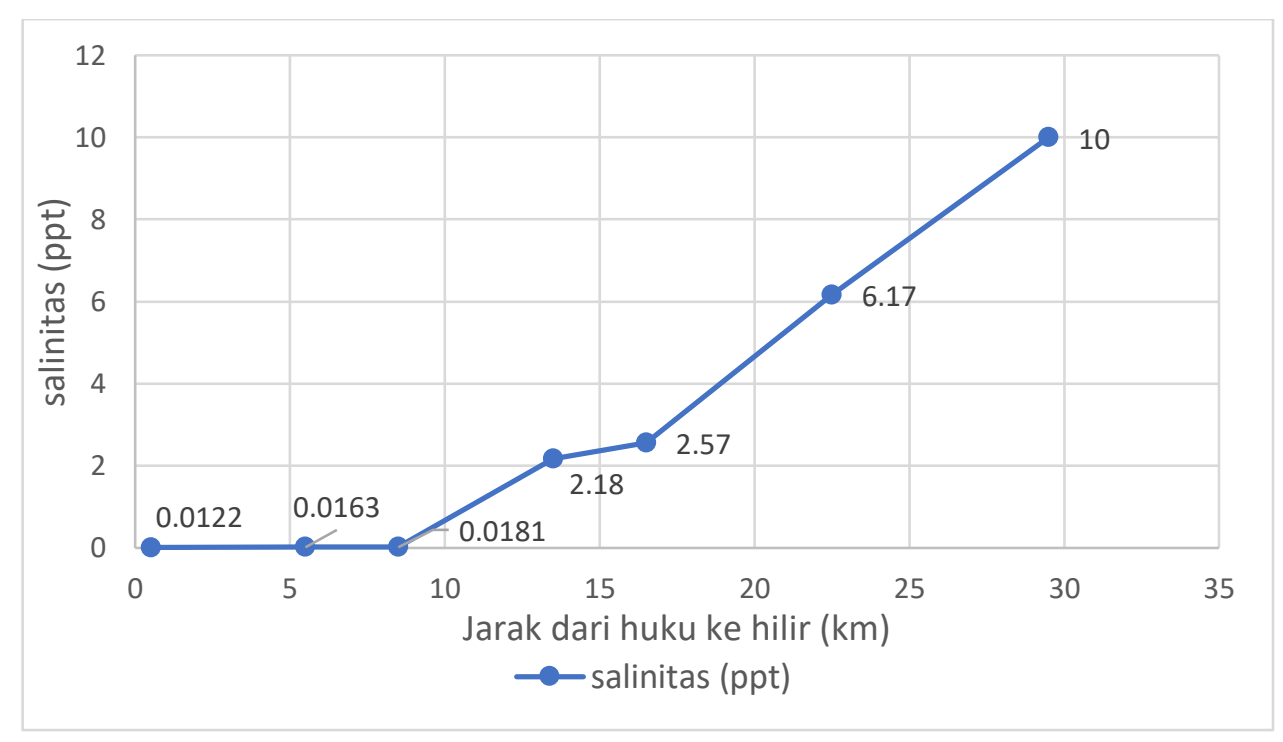

Gambar 3. Sebaran salinitas secara horizantal pada lokasi penelitian

Sumber: Purnaini, et al.,(2017) 

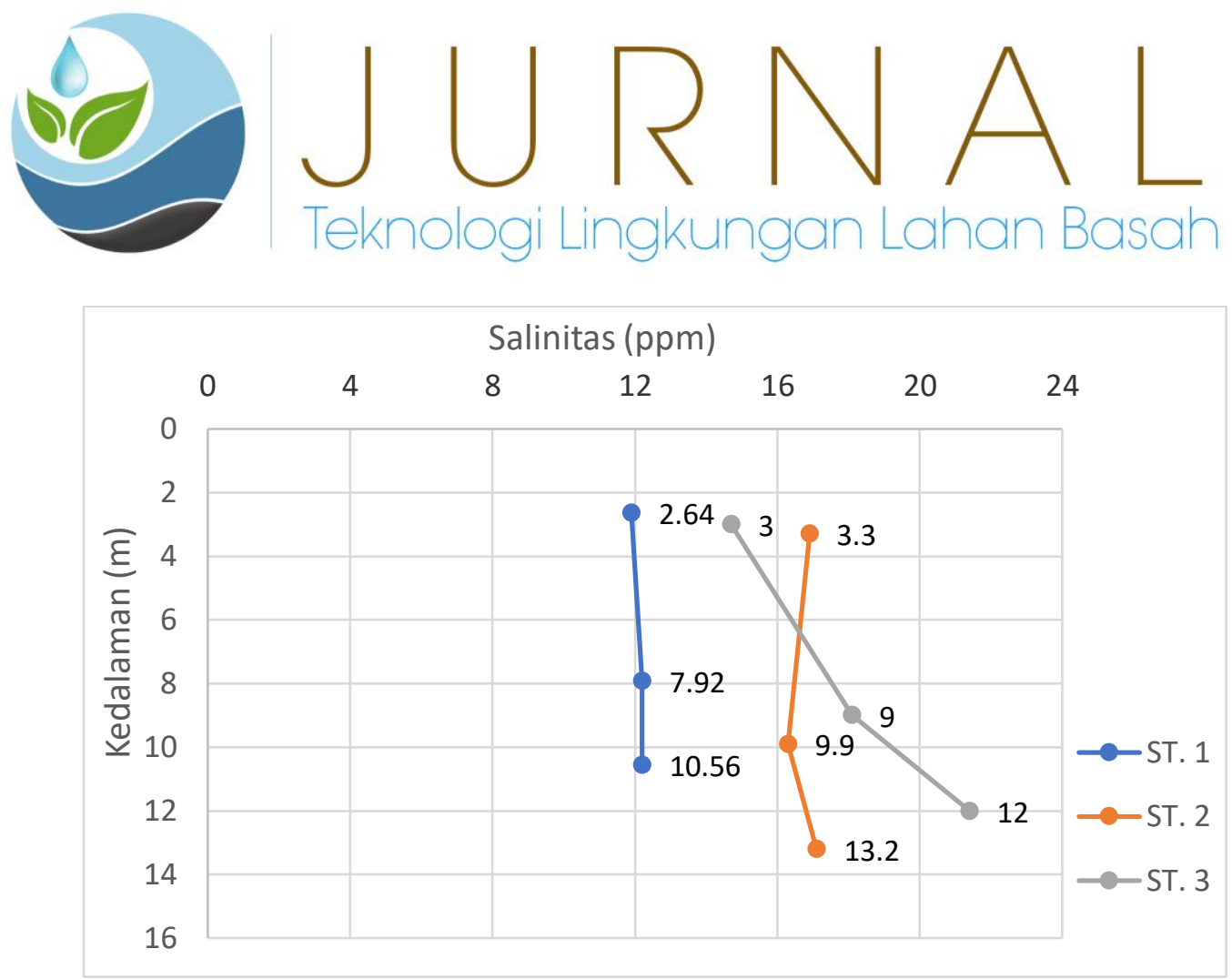

Gambar 4. Sebaran salinitas secara vertikal pada bagian hulu lokasi penelitian Sumber: Purnaini, et al.,(2017)

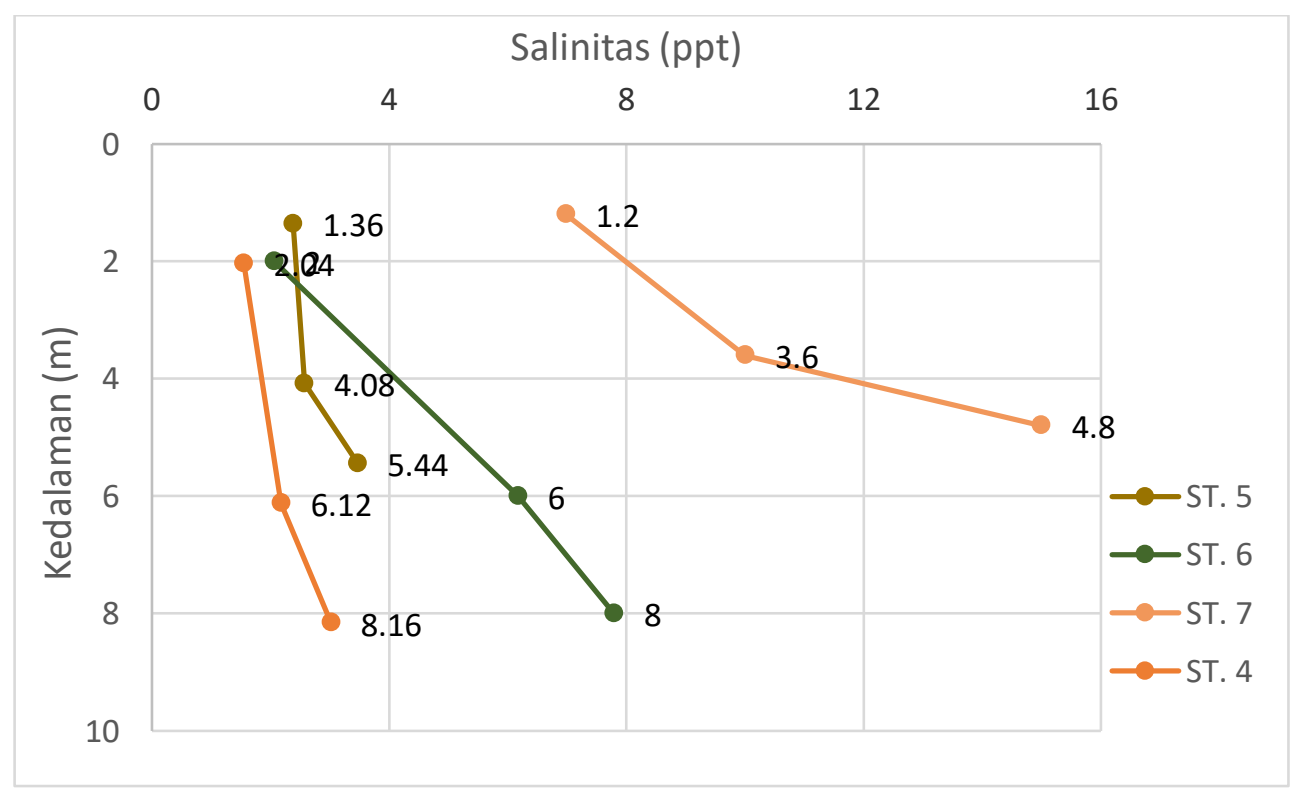

Gambar 5. Sebaran Salinitas Secara Vertikal Pada Bagian Hilir Lokasi Penelitian Sumber: Purnaini, et al.,(2017)

Pengaruh pasang surut terhadap sebaran salinitas juga ditunjukkan dengan konsentrasi TDS yang juga semakin meningkat ke arah hilir pada saat pasang (Gambar 6). TDS (Total Dissolved Solid) menggambarkan ion- ion terlarut di dalam 

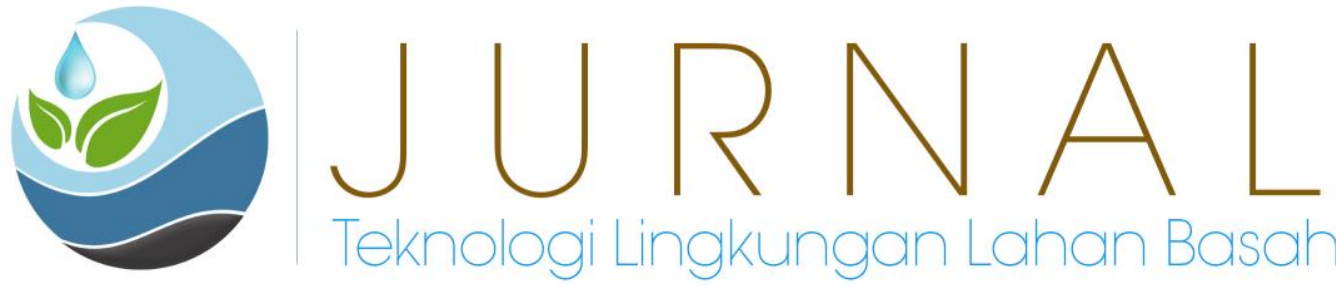

air (Effendi, 2003). Kadar TDS di lokasi penelitian pada saat pasang umumnya semakin meningkat ke arah hilir (muara) dan sudah melebihi kriteria mutu air Kelas I yaitu $1.000 \mathrm{mg} / \mathrm{l}$, Peningkatan nilai TDS semakin ke hilir menunjukkan pengaruh pasang air laut yang masuk ke sungai, nilai TDS yang tinggi juga menunjukkan nilai salinitas yang tinggi.

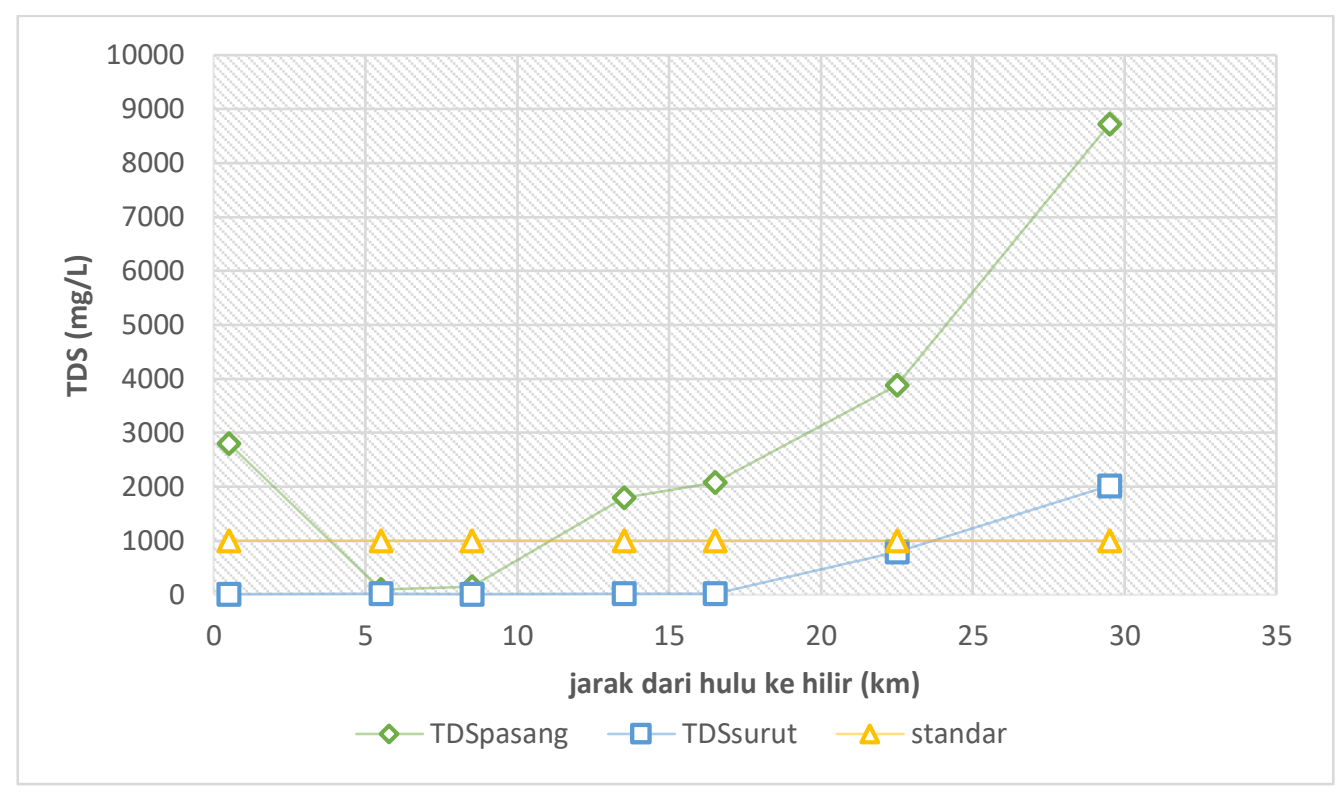

Gambar 6. Konsentrasi TDS di Sungai Kapuas Kecil

Sumber: Purnaini, et al.,(2017)

Hasil analisis menggunakan metode statistik regresi linier berganda didapatkan bahwa terdapat hubungan antara elevasi pasang surut dan jarak terhadap kualitas air sebesar $91 \%$, dilihat dari nilai koefisien korelasi (R).

Selanjutnya didapatkan nilai koefisien determinasi (adjusted $R$ square $)=0,760$; nilai ini secara keseluruhan menunjukkan bahwa variabel bebas yaitu elevasi pasang surut dan jarak berpengaruh terhadap kualitas air (nilai TDS) sebesar $76 \%$ (Purnaini, et al., 2018)

\section{PENUTUP}

Kesimpulan yang dapat diambil dari hasil analisis dan pembahasan adalah sebagai berikut:

1. Sebaran salinitas secara horizontal di Sungai Kapuas Kecil dari hulu ke hilir cenderung terus meningkat pada saat pasang dengan jarak jangkauan air laut mencapai $\pm 20 \mathrm{~km}$ ke arah hulu sungai dengan nilai salinitas berkisar $1,5 \mathrm{ppt}$.

2. Sebaran salinitas secara vertikal pada 3 lapisan kedalaman menunjukkan peningkatan salinitas dari lapisan permukaan menuju dasar perairan.

3. Berdasarkan struktur salinitasnya tipe estuari Sungai Kapuas Kecil adalah "tercampur sebagian". 

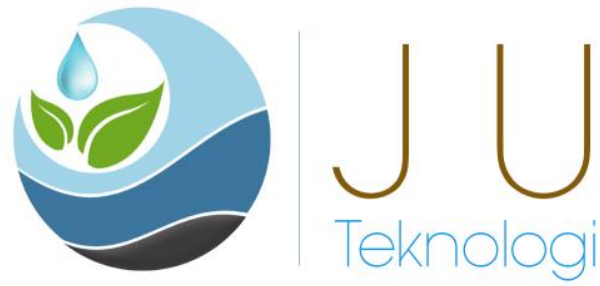

4. Hasil analisis regresi linier berganda didapatkan nilai koefisien determinasi (adjusted R square) $=0,760$, yang secara keseluruhan menunjukkan bahwa pasang surut dan jarak berpengaruh terhadap kualitas air (nilai TDS) sebesar $76 \%$.

\section{UCAPAN TERIMA KASIH}

Ucapan terima kasih penulis sampaikan kepada Direktorat Riset dan Pengabdian Masyarakat, Direktorat Jenderal Penguatan Riset dan Pengembangan, Kementerian Riset, Teknologi, dan Pendidikan Tinggi melalui bantuan dana hibah penelitian doktor 2017.

\section{DAFTAR PUSTAKA}

BMKG. (2016). Buletin Edisi September 2016. Stasiun Klimatologi Siantan. Pontianak.

Departemen Pekerjaan Umum. (2014). Laporan pekerjaan Rencana Jalan Outer Ringroad Kota Pontianak. Pontianak.

Dishiros TNI AL Indonesia. (2016). Daftar Pasang Surut Kepulauan Indonesia. Jakarta.

Dewi, A.K, Rochaddi, B., Rifai, A. (2016). Distribusi Salinitas Akibat Pengaruh Pasang Surut di Estuari Sungai Karangsong, Indramayu. JURNAL OSEANOGRAFI 5 1) 161-168.

Effendi, H. (2003). Telaah Kualitas Air; Bagi Pengelolaan Sumberdaya dan
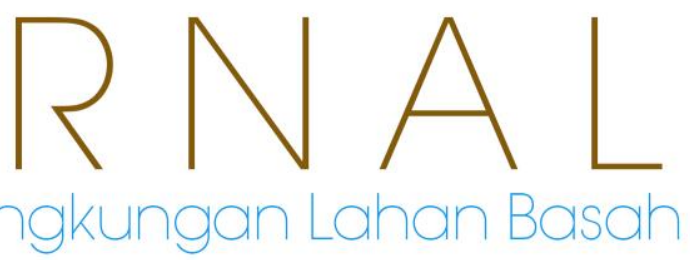

Lingkungan Perairan. Kanisius. Yogyakarta.

Fischer, H. B., List, E. J., Koh, R. C. Y., Imberger, J., Brooks, N. H., (1979). Mixing in Inland and Coastal Waters, Academic Press, Inc, United Kigdom.

Hutabarat, S., dan S. M. Evans. (2006). Pengantar Oseanografi. Departemen Pendidikan dan Kebudayaan, Jakarta.

https://kadarsah.wordpress.com/2007/06 /29/tiga-daerah-iklim-indonesia/.

Purnaini, R, Sudarmadji, Purwono, S. (2017). Kualitas Air Sungai Kapuas Kecil Bagian Hilir Pada Kondisi Pasang dan Surut, Proceeding Seminar Nasional Penerapan Ilmu Pengetahuan dan Teknologi, Universitas Tanjungpura, Pontianak.

Purnaini, R, Sudarmadji, Purwono, S. (2018). Tidal Influence on Water Quality of Kapuas Kecil River Downstream. E3S Web of Conferences 31, 04006, ICENIS 2017. Universitas Diponegoro. Semarang.

Sedyoko, D.A, Yusuf, M., Widada, S. (2013). Pengaruh Pasang Surut Terhadap Jangkauan Salinitas Di Sungai Sudetan Banger Kabupaten Pekalongan. JURNAL OSEANOGRAFI 2(1) 88-97.

Triatmodjo, B. (1999). Teknik Pantai. Beta Offset, Yogyakarta. 